\title{
EL ALUMBRADO (1986) DE GONZALO ROJAS
}

\section{Cristian Foerster Montecino}

El lugar del trono de Gonzalo Rojas en el panteón poético nacional -precedido por Mistral, Neruda, Huidobro y de Rokha-, a diferencia del de Parra, siempre ha estado en cuestión. Su obra no es monumental, como la de Neruda o de Rokha, ni misteriosa y profunda como la de Mistral, ni tampoco vanguardista-fundacional, como la de Parra o Huidobro. Su obra está compuesta por unos doscientos muy buenos poemas, reescritos hasta el cansancio, que conforman su extensa, pero no voluminosa bibliografía. A pesar de esto es, sin duda alguna, uno de los poetas más importantes de Chile, e incluso de Hispanoamérica, junto a Lihn, Teillier, Anguita, Rosamel del Valle, entre muchos, muchos otros.

Rojas es como Sileno, un dios menor, un viejo sátiro, sabio y borracho, que se pierde constantemente del cortejo de Dionisos (¿qué poeta sería nuestro Dionisos?), pero que conoce los secretos terribles de la vida. Rojas-Sileno, su obra integra, es el nexo entre un tiempo mítico de la poesía chilena, el de los viejos titanes, y el actual, quitado de bulla, gobernado desde la lejanía inconmensurable de Las Cruces, por Nicanor Parra.

Siguiendo esta línea, El Alumbrado (1986), poemario publicado por la extinta Ediciones Ganymides, continúa en la misma senda de sus libros anteriores. Los treinta y dos poemas (uno menos que la edad de Cristo) que componen este libro, giran en torno a los tópicos típicos que han hecho conocido al poeta: la lujuria, que es imaginación, confundida por él con el amor, la muerte y el hecho propio de crear poesía. Así, Gonzalo Rojas, en la actualidad, debe ser el gran maestro de la elegía del idioma español; y la erudición literaria atraviesa su obra y la vincula con toda la tradición poética del mundo. Dichas temáticas se funden y confunden unas con otras en estos poemas, que vinieron a alumbrar -y también a refrescar- una época de la historia de Chile oscurecida por la violencia de la dictadura. En este poemario se encuentran textos famosos como "Qedeshím Qedeshóth", poema sobre una prostituta que es violada apasionadamente por el hablante, o "Sebastián Acevedo", visión de un joven inmolado, quien encarna los sufrimientos de todo Chile bajo la represión militar, o también poemas menos conocidos, como "Round-Trip", inquietante reflexión o recorrido mental que comienza en una casa de Pablo Neruda -que puede ser La Sebastiana o la de Isla Negra- y que finaliza en el sinsentido de su presencia en ese lugar.

En este poemario, como en todo buen libro que vale la pena leer, e incluso releer, reside un secreto, un secreto a voces, pero que Rojas -he aquí una de sus genialidadeshace aparecer como algo novedoso: la poesía es luz, pero también oscuridad. Pienso en esto y no puedo evitar recordar la primera y última vez que escuché al viejo Rojas recitar. Fue en el Congreso "Chile mira a sus Poetas", realizado por la Universidad Católica, el año 2009. El poeta leyó y brilló, deslumbrando a todos los espectadores, en especial a las autoridades de dicha casona de estudios, quienes escucharon estupefactos versos como: 
Pero ahora, ay, hablando en prosa se

entenderá que tanto

espectáculo angélico hizo de golpe crisis en mi

espinazo, y lascivo y

seminal la violé en su éxtasis como

si eso no fuera un templo sino un prostíbulo, la

besé áspero, la

lastimé y ella igual me

besó en un exceso de pétalos, nos

manchamos gozosos, ardimos a grandes llamaradas (Pág. 35.)

Rojas, esa noche, más que un poeta que lee con cierto recelo sus poemas, fue un rockstar, el único rockstar que ha tenido esta isla de país, pues su vozarrón asfixiado resonó estridente y sin tapujos de ningún tipo en un salón mojigato cuyo nombre no recuerdo. En ese instante, el poeta me pareció un ser venido de otro tiempo, un tiempo en que los poetas eran respetados y su sola voz llenaba estadios y hacía feliz a la gente. Esa misma sensación me produjo la lectura de El Alumbrado: estar leyendo algo procedente de otra época, una pasada que no me tocó vivir y que contemplo como si fuera la luz tenue de una estrella distante.

En conclusión, vale más que la pena leer, e incluso releer, este poemario y toda la obra de Gonzalo Rojas, el más joven de los viejos poetas de la tribu, pues su luz y oscuridad, aire sucio sobre aire puro, es una brisa potente que siempre refrescará el contaminado panorama poético nacional, más allá o más acá de su reciente muerte, que esta reseña de algún modo homenajea. 